\title{
Corporate Social Responsibility: A Cross-National Study of the Treatment of Consumers and Employees
}

http://doi.org/10.21272/bel.4(2).6-15.2020

John Tsalikis, ORCID: https://orcid.org/0000-0001-5653-806X

$\mathrm{PhD}$, Professor, the Department of Marketing and Logistics, Florida International University, USA

Bruce Seaton, ORCID: https://orcid.org/0000-0003-4525-543X

$\mathrm{PhD}$, Associate Professor, the Department of Marketing and Logistics, Florida International University, USA

\begin{abstract}
Within a CSR framework, this paper reports on an extensive array of studies which explore consumer and employee issues with businesses in 13 countries, including the United States and countries in Eastern and Western Europe, Latin America, Asia, and the Middle East. The relevance of this study is based on the idea that consumer trust and fair treatment of employees are both core components of CSR and vital elements of economic efficiency and satisfaction from both supplier and customer perspectives. The questionnaires included open-ended inquiries which employed the technique of unaided recall, alternatively known as "top of mind" awareness. This method's strength is that it provides minimum direction to respondents, thus avoiding interviewer bias. The resulting data were examined and classified using the method of content analysis. The results indicate that in Mexico and Argentina most consumer complaints involved price, while in Russia, China, and India consumers complained about aspects of product policy. Only Brazilian consumers registered their major concern as complaints on service. The complaints about corporate policy focused on the poor treatment of employees. The between-country contrasts were often large; for example, $26 \%$ of Japanese respondents expressed concerns about employee issues whereas such complaints were limited to $3 \%$ of our Mexican sample. The strength of the current research is the combination of the breadth of the study (13 countries) coupled with the employment of national probability samples. The corresponding limitation stems from the limited depth of inquiry associated with the methodology employed and the inherent complexity of cross-national comparisons. The key implication of the paper is that both customers and employees have numerous complaints regarding the treatment they receive from corporations, but these issues show significant differences between the countries in the sample. In depth examination of the individual countries is one of several fruitful areas suggested for further research.
\end{abstract}

Keywords: Corporate Social Responsibility (CSR), Consumer Complaints, Price, Product, Service.

JEL Classification: M14, D12, E3.

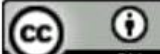

This work is licensed under a Creative Commons Attribution 4.0 International License

Cite as: Tsalikis, J., Seaton, B. (2020). Corporate Social Responsibility: A Cross-National Study of the Treatment of Consumers and Employees. Business Ethics and Leadership, 4(2), 6-15. http://doi.org/10.21272/bel.4(2).6-15.2020.

(C) The Authors, 2020. This article is published with open access at Sumy State University.

\section{Introduction}

Corporate Social Responsibility (CSR) is the idea that corporations are not only responsible to their stockholders for making a profit but should also be sensitive to social and environmental issues. A crucial point raised by Wang et al. (2016) is that corporations need to be proactive in their social responsibilities. CSR is exploding in relevance: "over 8,000 companies from more than 150 countries are signatories to the United Nations' Global Compact covering issues on human rights, labor standards, the environment, and anti-corruption initiatives" (Wang et al., 2016: 534). Ernst and Young (2012) argue that the importance of CSR is reflected in CSR's direct lines of communication with the top leadership of corporations. In CSR the focus changes from the narrow interest of stockholders to the broader interest of stakeholders which includes its employees, customers, suppliers, and the communities impacted by the corporation. This article will focus on the fair treatment of employees and 
consumers. According to Sharma (2013), "a good economic performance makes it possible to develop operations for the long term and to invest in the development and well-being of employees." In addition to providing a safe working environment, corporations should focus on just treatment and equal opportunities to all employees regardless of race, age, gender, sexual orientation or religion. The fair treatment of consumers has been a wellestablished principle of marketing and consumer satisfaction is strongly connected to profitability. Elements of consumer satisfaction include product safety, fair pricing, good service, truthful advertising, and selling techniques which provide useful non-misleading information.

\section{The Current Study}

Over the last 15 years the Business Ethics Index measured consumer sentiment towards the ethical behavior of businesses in the US (Tsalikis and Seaton, 2006, 2007) and in seventeen countries throughout the world (Tsalikis and Seaton, 2007, 2008a, 2008c; Tsalikis, Seaton and Li, 2008b; Tsalikis and Lassar, 2009; Tsalikis, Seaton and Shepherd, 2014). To understand the underlying reasons for consumers' reactions, the instrument included additional open-ended measures specifically aimed to capture consumers' personal experiences, or experiences they have heard of through word of mouth or the media, regarding corporations' ethical behavior. The open-ended question went as follows:

"What particular ethical or unethical behavior did you personally experience or hear from others or the media?"

The responses indicated that both examples of ethical and unethical behavior were provided. Subsequently, two follow up questions were asked to confirm whether participant answers were referring to an ethical or unethical act and whether their responses were based on personal experience or external sources.

The purpose of the present study is to present the information collected from the open-ended questions throughout 13 countries and present it in a consolidated format. This study will provide insight into the perceptions of how corporations treated individuals both as consumers and employees, in a comprehensive set of countries. The study may be categorized as exploratory in that breadth of investigation is emphasized with the need for more in-depth studies a resultant area for further research. For example, the distinction between "personal experience" or "external sources" is important, but our sample sizes precluded such investigation in the present study.

\section{Literature Review}

Cross-Cultural Literature. In cross-cultural research, one school of thought posits the commonality of human nature and argues that a set of universal values and ethical standards exists (Bigoness and Blakely, 1996; Brown, 2013; Horodecka, 2014; Husted, Dozier, McMahon, and Kattan, 1996; Ralston, Holt, Terpstra, and Kai-Cheng, 1997). According to this philosophy, cultural differences are superficial and people in China exhibit the same ethical values as people in France. The other perspective posits that there are significant differences in cultural values that need to be studied and addressed when dealing with diverse cultures (Vogel, 1992).

Wines and Napier (1992) postulate that cultures are similar in moral values and different in the application of moral principles to specific situations. This latter perspective is more consistent with the relativistic approach that has come to dominate moral thought. In the relativistic tradition, Ferrell and Gresham (1985) introduced their "contingency framework for understanding ethical decision making." Rather than attempting to discover universal moral principles, they recommended the examination of contexts (i.e., cultural, historical, situational, or individual) and variables that influence ethical behavior.

Previous cross-cultural ethical studies have focused on managerial perceptions and values (Adelstein and Stewart, 2016; Cheten and Shindicka, 2017; Flores et al., 2015; Jackson, 2002, Palazzo 2002; Rittenburg and Valentine, 2002; Sampath et al., 2016; Valentine and Rittenburg, 2004). Such studies support cultural factors as influencing ethical beliefs and behavior. For example, Vitell and Paolillo (2004) found that "people from different countries use different ethical standards and evaluations." In their study, American businesspersons scored higher in ethicality than did their Spanish counterparts.

\section{Corporate Social Responsibility Literature}

In the early years of CSR research, studies performed in the US were dominant. However, more recently CSR studies have been performed in many countries including Germany (Shepherd et al., 2013), Japan (Bansal and Clelland, 2003) India (Krishnan and Kozhikode, 2015), and Australia (Tuscott, 2009), along with many others. 
CSR has blossomed as an idea in both the US and most of the world (Caroll, 2015; Maignan, 2001). While most studies in the field deal with the environmental dimension of CSR, a plethora of CSR research focuses on social, and economic aspects. The distinct feature of the present study is the focus on the fair treatment of consumers and employees. Employees are essential to an organization's success. Fair treatment of employee is one of the most important predictors of an organization's success. (Cameron,1994). Therefore, in this study we aim to shed light on the perceptions of how businesses in a comprehensive set of countries treated individuals both as consumers and employees.

CSR Studies on Consumers. Exforsys (2015) states that responsible corporations must deliver the right product, at the right quality, at the appropriate place, at a fair price, and with non-misleading advertising. Exforsys goes on to argue that by meeting the aforementioned criteria, customers' quality of living will improve. In a way, Exforsys views satisfaction not as an "objective" but rather as a "responsibility."

Bhattacharya and Sen (2004) argued that among a company's stakeholders, the customers are the most susceptible to the company's CSR activities. It is hypothesized that improved corporate social responsibility will lead to increased consumer goodwill towards the company or companies in question and ultimately contribute to increasing competitive advantage. Jayakumar and Geetha (2014) argued that "CSR has a positive influence on consumers' evaluations and purchase intentions. CSR is not only an ethical imperative but also an economic one." Their results showed that CSR led to an increased willingness to pay premium prices.

Chung et al. (2015) studied "how CSR factors influence customer satisfaction and loyalty" and found that corporate image has a moderating effect on this relationship. Mishina et al. (2010) examined product recalls and the effect on consumers. Their results show that prominent corporations tended to have more product recalls. Hartman (2011) argued that the food sector focuses on improving service towards its consumers. As a result, consumers prefer brands that offer good products and services. In a B2C context Bhattacharya and Sen (2004), have established a connection between a corporation's CSR activities and consumer satisfaction, loyalty and positive product perception. On the B2B segment, Hornburg et al. (2013) found that for B2B companies "carefully targeted CSR activities can raise organizational customers' trust and identification, both of which foster customer loyalty."

CSR Studies on Employees. On the employee side, Wang et al. (2016) argue that "while customers have been traditionally considered the key driver of companies' social initiatives, employees have become at least as important as, if not more important, than customers in driving company sustainability initiatives." As an example, Jones et al. (2014) show that CSR performance plays a role in attracting good employees through a signal-based mechanism. Moreover, in previous literature, Social Identity Theory (SIT) has been used to clarify the relation between the organizational identification and internal dimension of CSR (Riketta, 2005).

According to SIT, social identity is people's perception of who they are, and rests on their group membership. Within the context of CSR, employees identify themselves through the company they belong to and through the company initiatives (Olkkonen \& Lipponen, 2006; Glavas \& Godwin, 2013). This highlights the importance of alignment between corporate CSR activities and corporate fair treatment of employees.

Bauman and Skitka (2012) argued that "because employees are primary stakeholders who directly contribute to the success of the company, understanding employee reactions to corporate social responsibility may help answer lingering questions about the potential effects of corporate social responsibility on firms." In relation to employee needs, Bauman and Skitka suggest that CSR "can provide employees with (1) a sense of security and safety that their material needs will be met, (2) self-esteem that stems from a positive social identity, (3) feelings of belongingness and social validation of important values, and (4) existential meaning and a deeper sense of purpose at work."

Glavas and Kelley (2014), in a study, canvassing employees in eighteen companies, found that employee perceptions of CSR positively affected commitment to the firm and job satisfaction. Ali et al. (2010) argue that CSR can attract potential employees to the company by improving their working environment and promoting equitable growth opportunities.

Brammer et al. (2007) found that CSR increases employee commitment towards the company, while Koh and Boo (2001) argued that CSR practices lead to increased job satisfaction in employees. This increased satisfaction depends on involving employees in CSR decision making (Stawiski et al., 2010) and respecting employee rights, 
and paying fair wages while providing a safe workplace environment (Stancu et al., 2011). Chaturvedi (2013) reported that at Dell, the employees are the force behind Dell contributing more to societal issues. Albinger and Freeman (2000) argued that CSR enhances the corporation's ability to attract and keep talented employees.

\section{Methodology}

The verbatim results from the open-ended question were translated into English by the data collection companies and coded by the researchers using content analysis. As noted earlier, sample size limitation precluded the distinction between personal and external sources being included in the content analysis. The intercoder reliability varied by country and ranged from $79 \%$ to $87 \%$, which is acceptable in this type of research (Lombard, SnyderDuch and Bracken, 2002).

Samples. In the US, the sampling for all BEI determinations was obtained from the ORC International Telephone CARAVAN® survey. According to ORC:

"The study was conducted using two probability samples: randomly selected landline telephone numbers and randomly selected mobile (cell) telephone numbers. The combined sample consists of 1,008 adults (18 years old and older) living in the continental United States. Of the 1,008 interviews, 508 were from the landline sample and 500 from the cell phone sample. The margin of error for the sample of 1,008 is $+/-3.1 \%$ at the $95 \%$ confidence level. Smaller subgroups will have larger error margins. Surveys are collected by trained and supervised US-based interviewers using ORC International's computer-assisted telephone interviewing (CATI) system. Final data is adjusted to consider the two sample frames and then weighted by age, gender, region, race/ethnicity, and education to be proportionally representative of the US adult population." In addition to the US, similar surveys were conducted in 14 countries that were grouped into four distinct blocks:

Asia: China, Japan, India;

$>$ Eastern Europe: Russia, Poland, Romania, Bulgaria;

$>$ Latin America: Argentina, Bolivia, Brazil, Colombia, Mexico;

Middle East: Turkey, Egypt.

Because of local circumstances, not all data gathering was conducted through CATI systems. In Japan, due to a reluctance to phone interviews, an internet panel was used. In Eastern European and some Latin American countries, face-to-face interviews were conducted. In all instances the objective was to obtain a nationally representative sample.

\section{Results}

\section{Results on Consumer Perceptions}

Because of various technical reasons, the results for the open-ended questions were not usable for 2 of the 15 countries (Turkey, Colombia). For a clearer presentation of the data, the countries are grouped based on whether the country focused on Service, Product, or Price. These groupings are based on the response patterns within the national samples. It is important to emphasize that these patterns are entirely the result of the national sample data without interviewer prompting, ensuring that our information was "unaided recall". Of note is that advertising/selling did not predominate in any of the countries sampled.

Countries Emphasizing Product. The countries that emphasized the Product element in their perceptions are presented in Table 2. Russia had the highest focus on product with $65 \%$, followed by China (58\%), India (51\%), and Egypt at 47\%. While Poland's highest score was for Product element, the focus was significantly lower than the other four countries with only $28 \%$. For Russia, Egypt, and India the main complaint was "defective/low quality" products, Chinese respondents complained mostly about "fake/expired" products, while Poland has a more even distribution on all categories of product (with the highest percentage being "unsafe" products).

Countries Emphasizing Price. The countries that emphasized the Price element in their perceptions are presented in Table 3. All six countries in Table 3 focused mainly on price and Mexico and Argentina have the highest percentages for price ( $41 \%$ and $40 \%$ respectively), while Japan and US having the lowest focus on price (23\% and $24 \%$ ). Romania (31\%) and Bulgaria (29\%) had a moderate focus on price. Within all six countries the main complaint was "overcharging/price gouging." 
Results on Employee Issues. The detailed results on the employee issues are presented in Tables 1 to 3. For a clearer presentation, the employee issues results are summarized in Table 4. Table 4 shows that "poor employee treatment" received the most mentions (46\%) within all countries, followed by "bad management policies" $(38 \%)$ and "Fraud/Theft" (29\%). Poland had the most mentions on "poor employee treatment" (13\%), followed closely by Romania (12\%), Bulgaria (7\%), and USA (6\%) a distant fourth. For "bad management policies" Japan (17\%) was the leader, followed by Brazil (8\%) and Argentina (5\%). Finally, for "fraud/theft" Bulgaria (7\%) had a small lead over Romania (6\%), followed closely by USA (6\%) and Poland (4\%).

Table 1. Countries Focusing on Service

\begin{tabular}{|c|c|c|}
\hline & BRAZIL & BOLIVIA \\
\hline SERVICE & $32 \%$ & $24 \%$ \\
\hline Poor service & $8 \%$ & $24 \%$ \\
\hline Rudeness/discourteousness & $8 \%$ & \\
\hline Did not correct mistakes/problems & $6 \%$ & \\
\hline Poor quality work & $5 \%$ & \\
\hline Late delivery & $3 \%$ & \\
\hline Other & $3 \%$ & \\
\hline PRODUCT & $17 \%$ & $9 \%$ \\
\hline Defective/low quality products & $4 \%$ & $4 \%$ \\
\hline Fake/expired products & $5 \%$ & $5 \%$ \\
\hline Did not replace defective product/warranties & $4 \%$ & \\
\hline Did not deliver what was promised & $2 \%$ & \\
\hline Other & $3 \%$ & \\
\hline PRICE & $16 \%$ & $26 \%$ \\
\hline Overcharging/Price gouging & $6 \%$ & $26 \%$ \\
\hline Inaccurate billing & $9 \%$ & \\
\hline Other & $2 \%$ & \\
\hline ADVERTISING & $3 \%$ & \\
\hline False advertising/ exaggerated info & $3 \%$ & \\
\hline SELLING & $2 \%$ & \\
\hline Sales pressure/hard sell & $2 \%$ & \\
\hline EMPLOYEE ISSUES & $14 \%$ & $17 \%$ \\
\hline Bad management policies & $8 \%$ & $3 \%$ \\
\hline Poor treatment of employees & $2 \%$ & \\
\hline Theft/embezzlement/fraud & $2 \%$ & \\
\hline Discrimination/prejudice/bias & $1 \%$ & \\
\hline Other & & $14 \%$ \\
\hline
\end{tabular}

Source: Survey Data

Table 2. Countries Focusing on Product

\begin{tabular}{|c|c|c|c|c|c|}
\hline & RUSSIA & POLAND & EGYPT & CHINA & INDIA \\
\hline SERVICE & $14 \%$ & $13 \%$ & $21 \%$ & $6 \%$ & $5 \%$ \\
\hline Poor service & $9 \%$ & $3 \%$ & $21 \%$ & $2 \%$ & $3 \%$ \\
\hline Rudeness/discourteousness & $1 \%$ & $6 \%$ & & $4 \%$ & \\
\hline PRODUCT & $65 \%$ & $29 \%$ & $48 \%$ & $58 \%$ & $51 \%$ \\
\hline Defective/low quality products & $30 \%$ & $6 \%$ & $19 \%$ & $13 \%$ & $17 \%$ \\
\hline Fake/expired products & $18 \%$ & $6 \%$ & $14 \%$ & $29 \%$ & $9 \%$ \\
\hline Did not honor warranties & $3 \%$ & $5 \%$ & $10 \%$ & $1 \%$ & $5 \%$ \\
\hline Less product & $3 \%$ & $1 \%$ & $5 \%$ & $1 \%$ & $4 \%$ \\
\hline Unsafe product & $12 \%$ & $9 \%$ & & $14 \%$ & $9 \%$ \\
\hline Lied about product & & & & & $8 \%$ \\
\hline PRICE & $9 \%$ & $12 \%$ & $22 \%$ & $11 \%$ & $32 \%$ \\
\hline Overcharging/Price gouging & $6 \%$ & $10 \%$ & $20 \%$ & $8 \%$ & $18 \%$ \\
\hline Bad sales & $2 \%$ & & $2 \%$ & $3 \%$ & $6 \%$ \\
\hline Bait \& switch & $1 \%$ & $1 \%$ & & & $7 \%$ \\
\hline \multicolumn{6}{|l|}{ ADVERTISING } \\
\hline False advertising & $5 \%$ & $5 \%$ & & $13 \%$ & $7 \%$ \\
\hline SELLING & & $1 \%$ & & $1 \%$ & \\
\hline Sales pressure & & $1 \%$ & & $1 \%$ & \\
\hline
\end{tabular}


Table 2 (cont.). Countries Focusing on Product

\begin{tabular}{|c|c|c|}
\hline EMPLOYEE ISSUES & $25 \%$ & $11 \%$ \\
\hline Bad management policies & $3 \%$ & \\
\hline \multicolumn{3}{|l|}{ No social contribution } \\
\hline Poor treatment of employees & $1 \%$ & \\
\hline Fraud/problems with law & $13 \%$ & \\
\hline Discrimination/prejudice/bias & $4 \%$ & \\
\hline Ask for bribe/corruption & $1 \%$ & \\
\hline Bureaucracy & $2 \%$ & \\
\hline Other & & $11 \%$ \\
\hline
\end{tabular}

Source: Survey Data

Table 3. Countries Focusing on Price

\begin{tabular}{|c|c|c|c|c|c|c|}
\hline & ROM & BULG & MEX & ARG & JAPAN & USA \\
\hline SERVICE & $6 \%$ & $6 \%$ & $14 \%$ & $9 \%$ & $19 \%$ & $12 \%$ \\
\hline Poor service & $3 \%$ & $1 \%$ & $11 \%$ & $9 \%$ & $19 \%$ & $6 \%$ \\
\hline Rudeness/discourteousness & $1 \%$ & $4 \%$ & $2 \%$ & & & $6 \%$ \\
\hline PRODUCT & $14 \%$ & $21 \%$ & $23 \%$ & $27 \%$ & $18 \%$ & $7 \%$ \\
\hline Defective/low quality products & $7 \%$ & $14 \%$ & $5 \%$ & $11 \%$ & $18 \%$ & $3 \%$ \\
\hline Fake/expired products & $3 \%$ & $4 \%$ & $2 \%$ & $7 \%$ & & \\
\hline Did not honor warranties & $2 \%$ & & $4 \%$ & $9 \%$ & & $4 \%$ \\
\hline Less product & $2 \%$ & $2 \%$ & $5 \%$ & & & \\
\hline Misrepresented product & $1 \%$ & & $5 \%$ & & & \\
\hline PRICE & $32 \%$ & $29 \%$ & $41 \%$ & $40 \%$ & $24 \%$ & $2 \%$ \\
\hline Overcharging/Price gouging & $29 \%$ & $28 \%$ & $31 \%$ & $36 \%$ & $15 \%$ & \\
\hline Bad sales & & & $5 \%$ & & $5 \%$ & \\
\hline Inaccurate billing & $2 \%$ & $1 \%$ & $2 \%$ & $4 \%$ & & \\
\hline Bait \& switch & $1 \%$ & & $3 \%$ & & & \\
\hline Aggressive collection & & & & & $4 \%$ & \\
\hline ADVERTISING & $3 \%$ & & $7 \%$ & & $10 \%$ & $8 \%$ \\
\hline False advertising & $3 \%$ & & $7 \%$ & & $10 \%$ & $8 \%$ \\
\hline SELLING & & & & & $3 \%$ & $1 \%$ \\
\hline Sales pressure & & & & & $3 \%$ & $1 \%$ \\
\hline EMPLOYEE ISSUES & $24 \%$ & $17 \%$ & $3 \%$ & $14 \%$ & $26 \%$ & $16 \%$ \\
\hline Bad management policies & $2 \%$ & & & $5 \%$ & $16 \%$ & \\
\hline Poor treatment of employees & $12 \%$ & $7 \%$ & $3 \%$ & $4 \%$ & & $6 \%$ \\
\hline Fraud/Theft & $6 \%$ & $7 \%$ & & $4 \%$ & & $6 \%$ \\
\hline Stock market mischief & & & & & $9 \%$ & \\
\hline High CEO compensation & & & & & & $3 \%$ \\
\hline
\end{tabular}

Source: Survey Data

Table 5. Analysis of Employee Issues

\begin{tabular}{|c|c|c|c|c|c|}
\hline & Mean* & POLAND & ROMANIA & BULGARIA & USA \\
\hline \multirow[t]{2}{*}{ Poor employee treatment } & $3.5 \%$ & $13 \%$ & $12 \%$ & $7 \%$ & $6 \%$ \\
\hline & & JAPAN & BRAZIL & ARGENTINA & \\
\hline \multirow[t]{2}{*}{ Bad management Policies } & $2.9 \%$ & $17 \%$ & $8 \%$ & $5 \%$ & \\
\hline & & BULGARIA & ROMANIA & USA & POLAND \\
\hline Fraud/Theft & $2.3 \%$ & $7 \%$ & $6 \%$ & $6 \%$ & $4 \%$ \\
\hline
\end{tabular}

Source: Survey Data

\section{Conclusions}

The results of the study indicate that different nations focused on different aspects of marketing, with Romania, Bulgaria, Mexico, Argentina, Japan, and the US focusing on price, while Russia, Poland, Egypt, China, and India focused on product. Only one of the thirteen countries (Brazil) focused on service, and one (Bolivia) equally focused on service and price. Whether these distinctions are permanent or transient (circumstances dependent) cannot be determined from the cross -sectional research presented in this paper. Whichever of the above options prevails the determination of the causal factor(s) is an area of ongoing interest. A major point of emphasis is that 
these categories were determined by the respondents themselves, the researchers using content analysis to characterize and classify ex post facto.

For the six countries focusing on price, the main complaint was "overcharging/price gouging." For the countries focusing on product, three groups appeared:

Russians, Egyptians, and Indians complained about "defective/low quality" products, Chinese complained mostly about "fake/expired" products.

$>$ Polish had a more even distribution on all categories of product (with the highest percentage being "unsafe" products).

$>$ For Brazil, the only country focusing on service, the two main complaints were "poor service/not helpful" (8\%) and "rudeness/discourteousness" (8\%).

As far as employee issues are concerned, "poor treatment of employees" and "bad management policies" received the most mentions, followed by "fraud/theft." The "poor treatment of employees" seems to be concentrated in the former Eastern Block countries of Poland, Romania and Bulgaria. The same three countries had the most mentions for "fraud/theft." While Japan had by far the most mentions for "bad management policies," the other two countries were from Latin America (Brazil and Argentina).

The implications of this study for managers and CSR officers are significant. Both customers and employees have a wide variety of complaints regarding the treatment they receive from corporations. These issues need to be investigated and addressed. While differences among countries were present, the main issues of consumers were focused mainly on poor service, substandard products, and high prices, while employees complained about poor treatment in the workplace and bad management policies. Based on the research of the relationship between consumer and employee satisfaction and profitability, policies addressing the above complaints should be given priority. The wide variety of complaints indicate that many of the issues involving CSR are locational and/or situation specific and thus require ongoing monitoring.

The above conclusions must be viewed through the lenses of the characteristics of both the methodology of unaided recall and content analysis and the inherent difficulties of cross-cultural content analysis. The content analysis was done by two researchers who were aware of their respective cultural biases and worked hard to minimize them. The translations from various languages to English were conducted by the research companies gathering the data.

It is apparent that this subject area is a fertile area for further research. A major problem is financing such a project which runs to tens of thousands of US dollars. However, the cost of not understanding the underlying dimensions for consumer and employee dissatisfaction with business behavior may be even more costly. An obvious extension of the current work would be more structured study of the underlying causes of both consumers' and employees' concerns with business behavior. The current research could support proposition and hypothesis development for more focused investigations.

\section{References}

1. Adelstein, J. and Clegg, S., (2016). Code of Ethics: A Stratified Vehicle for Compliance. Journal of Business Ethics, 138(1), 53-66. DOI 10.1007/s10551-015-2581-9.

2. Albinger, H.S., and Freeman, S.J. (2000). Corporate social performance and attractiveness as an employer to different job seeking populations. Journal of Business Ethics, 28, 243-253. https://doi.org/10.1023/A:1006289817941.

3. Ali, I., Rehman, K.U., Ali, S.I., Yousaf, J. and Zia, M. (2010). CSR influences employee commitment and organizational performance. African Journal of Business Management, 4(12), 2796-2801. Available at: https://www.scirp.org/(S(351jmbntvnsjt1aadkposzje))/reference/ReferencesPapers.aspx ?ReferenceID=1869836. 4. Bansal, P., and Clelland, I. (2004). Talking trash: Legitimacy impression management, and unsystematic risk in the context of the natural environment. Academy of Management Journal, 47, 93-103. DOI:10.2307/20159562. 5. Bauman, C.W., and Skitka, L.J. (2012). Corporate social responsibility as a source of employee satisfaction. Research in Organizational Behavior, 32(20), 63-86. https://doi.org/10.1016/j.riob.2012.11.002. 
6. Bhattacharya, C.B. and Sen, S. (2004). Doing better at doing good. California Management Review, 47(1), 9-24. https://doi.org/10.2307/41166284.

7. Bigoness, W. J., \& Blakely, G. L. (1996). A Cross-national Study of Managerial Values. Journal of International Business $\quad$ Studies, 27(4), 739-748. Available at: https://econpapers.repec.org/article/paljintbs/v_3a27_3ay_3a1996_3ai_3a4_3ap_3a739-748.htm.

8. Brammer, S., Millington, A. and Rayton, B. (2007). The contribution of CSR to organizational commitment. International Journal of Human Resource Management, 18(10), 1701-1719. DOI: 10.1080/09585190701570866. 9. Brown, C. (2013). Human Nature, Science and International Political Theory. Journal of International Relations and Development, 16(4), 435-454. 10.1057/jird.2013.17.

10. Cameron, K. S. (1994). Strategies for successful organizational downsizing. Human resource management, 33(2), 189-211. https://doi.org/10.1002/hrm.3930330204.

11. Carroll, A. B. (2015). Corporate Social Responsibility: The Centerpiece of Competing and Complementary Frameworks. Organizational Dynamics, 44(2), 87-96. https://doi.org/10.1016/j.orgdyn.2015.02.002.

12. Chaturvedi, A. (2013). Companies give employees a nudge for corporate social responsibility. The Economic Times, (11 January). 10.13140/RG.2.2.25379.76322.

13. Cheteni, P., \& Shindika, E. S. (2017). Ethical Leadership in South Africa and Botswana. BAR-Brazilian Administration Review, 14(2). https://doi.org/10.1590/1807-7692bar2017160077.

14. Chung, Ki-Han, Yu, Ji-Eun, Choi, Myeong-Guk and Shin, Jae-Ik. (2015). The effects of CSR on customer satisfaction and loyalty in China: The moderating role of corporate image. Journal of Economics, Business and Management, 3(5). DOI: 10.7763/JOE BM.2015.V3.243.

15. Ernst and Young. (2012). Six growing trends in corporate sustainability. New York. NY: EYGM Limited. Available at: http://www.fusbp.com/wp-content/uploads/2010/07.

16. Exforsys. (2019). CSR towards customers. www. Exforsys.com. 4/19/2019. Available at: http://www.exforsys.com/career-center/corporate-social-responsibility/corporate-social-responsibility-towardscustomers.html.

17. Ferrell, O. C., \& Gresham, L. G. (1985). A Contingency Framework for Understanding Ethical Decision Making in Marketing. The Journal of Marketing, 87-96. DOI: 10.2307/1251618.

18. Flores, W., Holm, H., Nohlberg, M., \& Ekstedt, M. (2015). Investigating Personal Determinants of Phishing and the Effect of National Culture. Information \& Computer Security, 23(2), 178-199. https://doi.org/10.1108/ICS-05-2014-0029.

19. Glavas, A., \& Godwin, L. N. (2013). Is the perception of 'goodness' good enough? Exploring the relationship between perceived corporate social responsibility and employee organizational identification. Journal of business ethics, 114(1), 15-27. DOI: 10.1007/s10551-012-1323-5.

20. Glavas, A., and Kelley, K. (2014). Perceived corporate social responsibility on employees' attitudes. Business Ethics Quarterly, 24(2), 165-202. DOI: 10.5840/beq20143206.

21. Hartman, M. (2011). CSR in the food sector. European Review of Agricultural Research, 38(3), 297-324. https://doi.org/10.1093/erae/jbr031.

22. Homburg, C., Stierl, M., and Bornerman, T. (2013). CSR in Business-to-Business markets: How organizational customers account for supplier CSR engagement. Journal of Marketing, 77, 54-72. DOI: $10.1509 / \mathrm{jm} .12 .0089$.

23. Horodecka, A. (2014). The Meaning of Concepts of Human Nature in Organizational Life in Business

Ethics Context. Annales, Ethics in Economic Life, 17(4), 53-64. Available at: http://www.annalesonline.uni.lodz.pl/archiwum/2014/2014_4_horodecka_53_64.

24. Husted, B. W., Dozier, J. B., McMahon, J. T., \& Kattan, M. W. (1996). The Impact of Cross-national Carriers of Business Ethics on Attitudes about Questionable Practices and Form of Moral Reasoning. Journal of International Business Studies, 27(2), 391-411. https://doi.org/10.1057/palgrave.jibs.8490141.

25. Jackson, T. (2000). Management Ethics and Corporate policy: A Cross-cultural Comparison. Journal of Management Studies, 37(3), 349-369. DOI: 10.1111/1467-6486.00184.

26. Jatana, R., and Crowler, D. (2007). CSR and the empowerment of women: An Indian perspective. Social Responsibility Journal, 3(4), 40-48. https://doi.org/10.1108/17471110710840224.

27. Jayakumar, A., and Geetha, K. (2014). An analysis on consumer perception towards CSR practices in Salem city. Proceedings of the Second International Conference on Global Business, Economics, Financial and Social 
Sciences ISBN:978-1-941505-14-4, Chennai, India. Available at: http://globalbizresearch.org/chennai_conference/pdf/pdf/ID_C4107_Formatted.pdf.

28. Jones, D.A., Willness, C.D., and Masey, S. (2014). Why are job seekers attracted by corporate social performance? Experimental and field test of three signal-based mechanisms. Academy of Management Journal, 57, 383-404. https://doi.org/10.5465/amj.2011.0848.

29. Koh, H.C., and Boo, E.H.Y., (2001). The link between organizational ethics and job satisfaction: A study of managers in Singapore. Journal of Business Ethics, 29, 309-324. https://doi.org/10.1023/A:1010741519818.

30. Krishnan, R., and Kozhikode, R. (2015). Status and corporate illegality: Illegal loan recovery practices and commercial banks in India. Academy of Management Journal, 58, 1287-1312. https://doi.org/10.5465/amj.2012.0508.

31. Lombard, M., Snyder-Duch, J., \& Bracken, C. C. (2002). Content Analysis in Mass Communication: Assessment and Reporting of Intercoder Reliability. Human Communication Research, 28(4), 587-604. https://doi.org/10.1111/j.1468-2958.2002.tb00826.x.

32. Maignan, I. (2001). Consumers' Perceptions of Corporate Social Responsibilities: A Cross-cultural Comparison. Journal of Business Ethics, 30(1), 57-72. https://doi.org/10.1023/A:1006433928640.

33. Mishina, Y., Dykes, B.J., Block, E.S., and Pollock, T.G. (2010). Why "good" firms do bad things: The effects of high aspiration, high expectations, and prominence on the incidence of corporate illegality. Academy of Management Journal, 53, 701-722. https://doi.org/10.5465/amj.2010.52814578.

34. Olkkonen, M. E., \& Lipponen, J. (2006). Relationships between organizational justice, identification with organization and work unit, and group-related outcomes. Organizational behavior and human decision processes, 100(2), 202-215. DOI: 10.1016/j.obhdp.2005.08.007.

35. Palazzo, B. (2002). US-American and German Business Ethics: An Intercultural Comparison. Journal of Business Ethics, 41(3), 195-216. https://doi.org/10.1023/A:1021239017049.

36. Ralston, D. A., Holt, D. H., Terpstra, R. H., \& Kai-Cheng, Y. (1997). The Impact of Natural Culture and Economic Ideology on Managerial Work Values: A Study of the United States, Russia, Japan, and China. Journal of International Business Studies, 28(1), 177-207. Available at: https://www.jstor.org/stable/25483241?seq=1 .

37. Riketta, M. (2005). Organizational identification: A meta-analysis. Journal of vocational behavior, 66(2), 358-384. https://doi.org/10.1016/j.jvb.2004.05.005.

38. Rittenburg, T. L., \& Valentine, S. R. (2002). Spanish and American Executives' Ethical Judgments and Intentions. Journal of Business Ethics, 38(4), 291-306. DOI: https://doi.org/10.1023/A:1016013326063.

39. Sampath, V. S., Gardberg, N. A., \& Rahman, N. (2018). Corporate Reputation's Invisible Hand: Bribery, Rational Choice, and Market Penalties. Journal of Business Ethics, 151(3), 743-760. DOI:10.1007/s10551-016-3242-3.

40. Sharma, Y. (2013). Role of Corporate Social Responsibility in organizations, Journal of Business and Management, 13(4), 1-8. Available at: http://www.iosrjournals.org/iosr-jbm/papers/Vol13issue4/A01340108.pdf.

41. Shepherd, D.A., Patzelt, H., and Baron, R.A. (2013). I care about nature but...: Disengaging values in assessing opportunities that cause harm. Academy of Management Journal, 56, 1251-1273. Available at: https://www.jstor.org/stable/43589216.

42. Stancu, A., Grigore, G.F., and Rosca, M.I. (2011). The impact of CSR on employees. IPEDR, 21, 11-16. Available at: http://www.ipedr.com/vol21/3-ICIF2011-A00024.pdf.

43. Stawiski, S., Deal, J.J., and Gentry, W. (2010). Employees perceptions of corporate social responsibility: The implications for your organization. Quick View Leadership Series, Center for Creative Leadership, USA. Available at: https://www.ccl.org/wpcontent/uploads/2015/02/EmployeePerceptionsCSR.pdf.

44. Truscott, R.A., Bartlett, J.L., and Stephane, A.T. (2009). The reputation of CSR industry in Australia. Australasian Marketing Journal, 17(2), 84-91. DOI: 10.1016/j.ausmj.2009.05.001.

45. Tsalikis, J. (2011). The Business Ethics Index as a Leading Economic Indicator. Journal of Business Ethics, 99(4), 519-525. https://doi.org/10.1007/s10551-010-0664-1.

46. Tsalikis, J., \& Lassar, W. (2009). Measuring Consumer Perceptions of Business Ethical Behavior in two Muslim Countries. Journal of Business Ethics, 89(1), 91-98. https://doi.org/10.1007/s10551-008-9986-7.

47. Tsalikis, J., \& Seaton, B. (2006). Business Ethics Index: Measuring Consumer Sentiments toward Business Ethical Practices. Journal of Business Ethics, 64(4), 317-326. https://doi.org/10.1007/s10551-005-4667-2. 
48. Tsalikis, J., \& Seaton, B. (2007). The International Business Ethics Index: European Union. Journal of Business Ethics, 75(3), 229-238. https://doi.org/10.1007/s10551-006-9249-4.

49. Tsalikis, J., \& Seaton, B. (2007). Business Ethics Index: USA 2006. Journal of Business Ethics, 72(2), 163-175. Available at: https://www.jstor.org/stable/25075369.

50. Tsalikis, J., \& Seaton, B. (2008). Consumer Perceptions of Business Ethical Behavior in Former Eastern Block Countries. Journal of Business Ethics, 82(4), 919-928. https://doi.org/10.1007/s10551-007-9602-2.

51. Tsalikis, J., \& Seaton, B. (2008). The International Business Ethics Index: Japan. Journal of Business Ethics, 80(2), 379-385. https://doi.org/10.1007/s10551-007-9427-z.

52. Tsalikis, J., Seaton, B., \& Li, T. (2008). The International Business Ethics Index: Asian Emerging Economies. Journal of Business Ethics, 80(4), 643-651. https://doi.org/10.1007/s10551-007-9459-4.

53. Tsalikis, J., Seaton, B., \& Shepherd, P. L. (2014). Business Ethics Index: Latin America. Journal of Business Ethics, 119(2), 209-218. Available at: www.jstor.org/stable/42921285.

54. Tsalikis, J., Van Solt, M. \& Seaton, B. (2019), Measuring Consumers' Perceptions of Business Ethicality on Price, Product, and Service Domains. Cross Cultural \& Strategic Management, 26(4), 451-466. https://doi.org/10.1108/CCSM-01-2019-0017.

55. Valentine, S. R., \& Rittenburg, T. L. (2004). Spanish and American Business Professionals' Ethical Evaluations in Global Situations. Journal of Business Ethics, 51(1), 1-14. https://doi.org/10.1023/B:BUSI.0000032384.74020.a8.

56. Vitell, S. J., \& Paolillo, J. G. (2004). A Cross-cultural Study of the Antecedents of the Perceived Role of Ethics and Social Responsibility. Business Ethics: A European Review, 13(2-3), 185-199. https://doi.org/10.1111/j.1467-8608.2004.00362.x.

57. Vogel, D. (1992). The Globalization of Business Ethics: Why America Remains Distinctive. California Management Review, 35(1), 30-49. https://doi.org/10.2307/41166711.

58. Wang, H., Tong, L., Takeuchi, R., and Gerard, G. (2016). Corporate Social Responsibility: An overview and new research directions. Academy of Management Journal, 59(2), 534-544. https://doi.org/10.5465/amj.2016.5001.

59. Wines, W. A., \& Napier, N. K. (1992). Toward an Understanding of Cross-cultural ethics: A Tentative Model. Journal of Business Ethics, 11(11), 831-841. https://doi.org/10.1007/BF00872361. 